\title{
UNDERLYING CHARACTERISTICS OF THE OVERALL DEVELOPMENT AND STRUCTURE OF AGRICULTURE IN THE COHESION REGIONS OF THE VISEGRAD COUNTRIES AFTER 2005
}

\author{
Denisa DVOŘÁKOVÁa, Věra BEČVÁŘOVÁ ${ }^{\mathrm{b}}$
}

\begin{abstract}
${ }^{a}$ Institute of Regional and Business Economics, Faculty of Regional Development and International Studies, Mendel University in Brno, Zemědělská 1665/1, 61300 Brno, denisa.m.dvorak@gmail.com

${ }^{b}$ Institute of Regional and Business Economics, Faculty of Regional Development and International Studies, Mendel University in Brno, Zemědělská 1665/1, 61300 Brno, vera.becvarova@gmail.com
\end{abstract}

Cite this article: Dvořáková, D., Bečvářová, V. (2021). Underlying characteristics of the overall development and structure of agriculture in the Cohesion Regions of the Visegrad countries after 2005. Deturope. 13(1), 7493.

\begin{abstract}
The paper deals with the development of the size and structure of agriculture in the Cohesion Regions of the Visegrad Group countries. It focuses on the specification of the basic tendencies of the development of this sector in the region of the Central Europe in the period after the accession of the Visegrad countries to the European Union in 2004. For this purpose, the dynamics of the development and structure of agriculture are analyzed and compared over a period of years 2005-2015 in the NUTS 2 regions of the V4 countries (the Czech Republic, Poland, Hungary, and Slovakia). The following indicators are used: total values of agricultural production, total values of crop production and total values of livestock production in millions of euros. The analyses carried out refute the generally proclaimed attempt to unify, or converge, the economies in this sector at the level of 35 Cohesion Regions. The beta convergence instrument presents a divergence tendency between NUTS 2 regions for all the indicators examined. The level of utilization of growth potential of Cohesion Regions from the indicators can also be assessed. Results of beta convergence analyses are graphically presented in the paper using correlation diagrams.
\end{abstract}

Keywords: Visegrad group, Cohesion regions, value of total agricultural production, value of total crop production, value of total livestock production, beta convergence, sigma convergence, correlation diagram.

\section{INTRODUCTION}

As an important part of the national and the global economy, the agrarian sector is discussed not only in terms of food security and in eradicating hunger, which is a problem in the developing countries, namely, but also in Europe today (Wittmer \& Gundimeda, 2012). In the future, too, agriculture shall play a dignified role of a partner to other economic sectors at the lower NUTS levels in particular (Bacsi \& Kovács, 2007). His rating is equally significant in terms of the irreplaceability in landscape care, addressing the consequences of climate change, sustainable management of natural resources, and last but not least, in connection 
with the threat to rural areas, which is closely related to the development of specific regions (EC, 2014).

These criteria are increasingly reflected in the strategy of the European model of multifunctional agriculture and in the concrete concept and implementation within the Common Agricultural Policy (CAP) in the Member States of the European Union (EU).

It now faces a new programming period 2021-2027 and sees it as a breakthrough period for the CAP in the future. The European Union strategy wants to simplify and modernize its framework; it also aims at supporting farmers as well as rural communities and the sustainable development of agriculture in the EU.

The proposal is strongly influenced by the achievement of the EU's higher environmental and climate targets (Green deal) to which conditionality should contribute, as well as the link between CAP payments per hectare and the scope of obligations (ES, 2020; Scown, Brady \& Nicholas, 2020).

Member States will gain more flexibility and responsibility in the new programming period. Its complexity is also confirmed by the adoption of an agreement within the EU on a transitional period in the years $2021-2022$.

Member States themselves will choose how and where CAP-based funding invests to meet the ambitious goals set by the EU itself and thus actively contribute to the creation of an intelligent, resilient, sustainable and competitive agrarian sector (Klöckner, 2018). According to Hogan (2018), this concept of the CAP grants genuine subsidiarity of the Member States in the field of agriculture. Katainena (2018) adds that more scope for Member States provides a more effective agricultural policy and enables easier monitoring of its results as well. This challenge and opportunity concern all Member States.

Therefore, it is appropriate to evaluate the current development trends of agriculture and characterize the basic causal links in the regions of the Central Europe during the period since the accession of the Visegrad countries to the European Union.

\section{BASIC BACKGROUND AND CONTEXT}

It is undeniable that agriculture in the 21 st century is increasingly changing with a broader view of a comprehensive and inclusive system that incorporates what today's agriculture does: listen to customers create value and deliver products and services from food, fiber, and natural resources as you drive and conservation of resources (Edwards \& Clifford, 2005). 
At present, the concept of agribusiness as a suitable approach that examines the issues of effective functioning of the entire food management system in the development of the business environment in its vertical and horizontal contexts is evaluated (Bečvárová \& Zdráhal, 2013; Zylbersztajn, 2017).

The basic philosophy of a common framework for modern agriculture development support under the Common Agricultural Policy of the EU thus requires the use of a dynamic access knowledge, specification, and use of competitive advantage in terms of its criteria in the application of policy in the individual Member States.

Already the accession of the Visegrad Group countries to the EU took place at a period of fundamental reform steps in the level and forms of support under the CAP. Typical for the development of the V4 countries in preparation and the first phase after accession and their participating in the EU common market was, however, noted by a reduction the competitive advantage (Jambor, 2013).

We should consider that the decrease in production in these states started already in the first half of the 1990s and then in the pre-admission period.

The starting positions of agriculture in the V4 countries when joining the EU were significantly different; this fact is due to previous agricultural developments, especially the different nature of the transformation of agriculture and the different level and degree of "socialization".

According to Bański (2008), the most significant changes were recorded in Hungary, where the land was returned to its original owners, which was related to a change in agricultural structure and land fragmentation.

The changes in the Czech Republic and Slovakia were already much smaller dramatic, with the leading process being constituted by the privatization of the assets already in the early nineties of the twentieth century.

In the case of Polish agriculture, after the transition to a market economy, the income of Polish farmers decreased, Zgliński (2008) estimated that 60 to $70 \%$ of farms found themselves in a difficult economic situation, which meant a loss of capacity for modernization and restructuring.

Yet, the basic economic processes and phenomena of the period of transformation appear to be similar, which is the consequence of the preparation to the accession to the $\mathrm{EU}$ according to the same procedures and stipulations. 
In the long term, the EU has highlighted the need for economic convergence of its regions, introduces the concept of cohesion (Baráth, Nagy, \& Szabó, 2010; Hansen \& Herrmann, 2012).

Monfort (2008) refers to the Treaty establishing the European Community, which stated that cohesion policy should "promote economic and social progress and a high level of employment and achieve balanced and sustainable development". Article 158 adds, „The Community's objective is in particular to reduce disparities between the levels of development of the various regions and the back protection of the least-favored regions or islands, including rural areas ".

Csaki and Jambor (2019) state: "There are many different ways to define and measure convergence in economics." De Jong (2018) defines convergence as "an act of rapprochement and, in particular, a move towards unity or uniformity".

The objective assessment of convergence or divergence between regions offers scope for the implementation of theories based on the neoclassical model of growth (Solow, 1956), based on the assumption that each of the regions examined has different growth potential, which can be measurable to some extent (Islam, 2003).

The course of the selected indicator over time according to Young et al. (2006), Nevima and Melecký (2008) is then examined using statistical tools in the field of growth economy and the so-called convergence models. Convergence itself is based on the assumption of a gradual levelling out of differences between regions and the so-called catching-up.

In connection with objectivization, i.e., measuring convergence between regions, it is possible to use the beta and sigma convergence methods (Minařík, 2014; Nevima \& Melecký 2008; Management association, 2017). This method of measuring convergence between regions, first used by Barro and Sala Martin (1995), laid the groundwork for research in this area (Obstfeld \& Rogoff, 1996).

Many studies based on convergence analyzes were carried out around 2005. However, these studies concern the economy as a whole, while fewer studies have been carried out for specific sectors, usually manufacturing (Alexiadis, 2010).

The aim of this paper is to objectify, evaluate and compare the position of agriculture and its development in the V4 countries and their individual Cohesion Regions (NUTS 2) within ten years of joining the EU and thus the CAP application capabilities. Specify the basic tendencies, including the development in the following years, and thus assess the manifestations and consequences of the application the CAP in the agriculture of these countries. 


\section{DATA AND METHODS}

The paper analyzes two basic statistical indicators: the share of agriculture in gross domestic product (GDP) and the share of agriculture in employment, the position of agriculture in the national economy of V4 countries and neighboring old member states Germany and Austria. Analyzes evaluate the development dynamics, scope, efficiency and final structure of agricultural production. Furthermore, for 35 NUTS 2 regions of the V4 countries, their ability to converge after joint accession to the EU are examined in the following indicators: total agricultural production, total crop and total livestock production in millions of euros at the basic price in 2005-2015. Newer data for regions not available.

These indicators are part of the Economic Account for Agriculture and can be implied for the purpose of analysing the production process of agricultural production. Data are also guaranteed to be comparable in time and space (Eurostat, 2020).

Statistical methods of beta and sigma convergence are applied in the paper to achieve the above-mentioned and a correlation diagram is presented at the end of the chapter.

Baumol (1986) state that according to the beta convergence method, individual regions converge over a certain period of time if the lower initial value of $\mathrm{y}_{0}$ in the $\mathrm{j}$-th region, where $\mathrm{j}$ $=1,2, \ldots, \mathrm{m}$, corresponds to the higher value of the region's average growth coefficient and vice versa.

Based on the method of least squares, equations of regression lines containing $\alpha$ and $\beta$ parameters are determined. In the case where $\beta<0$, the line is decreasing and the convergence tendency prevails. If $\beta>0$, then the line is increasing and the divergence tendency prevails. Consequently, the coefficients of determination (in \%) are determined:

$$
100 r^{2}=100 \frac{\operatorname{var} \log \bar{k}}{\operatorname{var} \log \bar{k}}
$$

Coefficients indicate the significance of the trend according to the achieved value ( $\max =$ $100, \min =0$ ).

While beta convergence focuses on detecting possible catching up processes, sigma convergence simply refers to a reduction of disparities among regions in time (Monfort, 2008). In the case of sigma convergence, we observe the standard deviation value, when the sigma convergence occurs, the variability of the monitored indicator decreases (Minařík, 2014). When beta convergence results in a low weight of analysis tool given by a low value of the determination coefficient, a correlation diagram is constructed using the following procedure.

In the correlation diagram, the logarithms of the initial values are plotted on the horizontal axis and the average growth coefficients are plotted on the vertical axis. Using averages, the 
diagram is then divided into 4 quadrants. Units with above-average initial values combined with above-average growth rates lie in the 1st quadrant. This means there is a tendency to move away from other units. Units with below-average initial values combined with aboveaverage growth rates lie in the 2nd quadrant. In the longer term, it can be assumed they will transfer to the 1 st quadrant. Units with below-average initial values combined with belowaverage growth rates lie in the 3rd quadrant. There is a tendency for them to lag behind other units. Units with above-average initial values combined with below-average growth rates lie in the 4th quadrant. In the longer term it can be assumed they will transfer to the 3rd quadrant.

Highly conclusive convergence is then demonstrated when the units of interest are in the second and fourth quadrants. On the other hand, for highly conclusive divergence, the units are in the first and third quadrant.

The adequate data for the paper are obtained from the EUROSTAT database and FADN. The analysis of statistical data is performed using MS Excel software and Statistica statistical software.

\section{RESULTS AND DISCUSSION}

The basic statistical indicators characterizing the position of agriculture in the economy is the share of agriculture in gross domestic product (GDP) and its share in employment, the V4 countries are, with their exceptions, above average compared to neighboring Germany and Austria (Tab. 1).

Table 1 The share of agriculture in GDP and employment in the V4 countries, Germany and Austria in percentage

\begin{tabular}{|l|c|c|c|c|c|c|}
\hline \multirow{2}{*}{ country } & \multicolumn{3}{|c|}{ The share of agriculture in GDP } & \multicolumn{4}{|c|}{ The share of agriculture in employment } \\
\cline { 2 - 7 } & 2005 & 2015 & 2019 & 2005 & 2015 & 2019 \\
\hline CZ & $2,2 \%$ & $2,2 \%$ & $1,9 \%$ & $3,8 \%$ & $2,9 \%$ & $2,7 \%$ \\
\hline HU & $3,7 \%$ & $3,8 \%$ & $3,5 \%$ & $6,5 \%$ & $4,9 \%$ & $4,7 \%$ \\
\hline PL & $2,9 \%$ & $2,2 \%$ & $2,2 \%$ & $17,4 \%$ & $11,5 \%$ & $9,2 \%$ \\
\hline SK & $1,6 \%$ & $2,6 \%$ & $2,5 \%$ & $6,9 \%$ & $4,8 \%$ & $2,2 \%$ \\
\hline DE & $0,7 \%$ & $0,7 \%$ & $0,7 \%$ & $2,4 \%$ & $1,4 \%$ & $1,2 \%$ \\
\hline AU & $1,3 \%$ & $1,1 \%$ & $1,1 \%$ & $5,3 \%$ & $4,5 \%$ & $3,6 \%$ \\
\hline
\end{tabular}

Source: The global economy (2020)

In general, the declining trend of these indicators is typical for the development of the position of the primary sector in the economies of developed countries. The decline is usually due to faster growth of other sectors of the national economy and labour productivity in agriculture and innovation in agricultural production and operations, but also changing, 
respectively stagnant demand for food in the regional market (Bečvářová, 2005; Bański, 2008; Spišiak, Ferenec, Ot’ahel \& Nováček, 2008).

The decline in these indicators is generally not a problem, but it is necessary to analyze the baseline and dynamics of the development on which are these indicators based. The key is the dynamics of the development of the value and final structure of total agricultural production, the influence of the development of the production dimension and the efficiency of the use of special land production factor and labour production factor (Bečvářová, 2008).

Analyzes of the indicators of total agricultural production, total crop production and total animal production are shown in Fig. 1, 2.

Figure 1 Total values of agricultural production in Million euro (2005-2019)

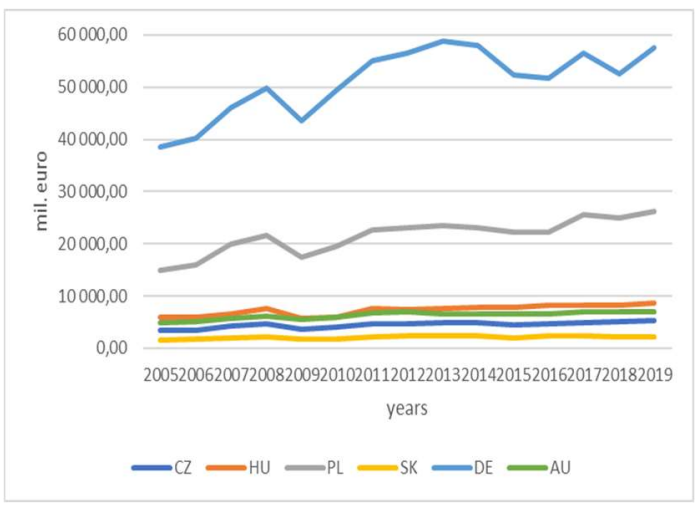

Source: EUROSTAT, own processing

Figure 2 Total crop production in Million euro and total livestock production in Million euro (2005-2019)
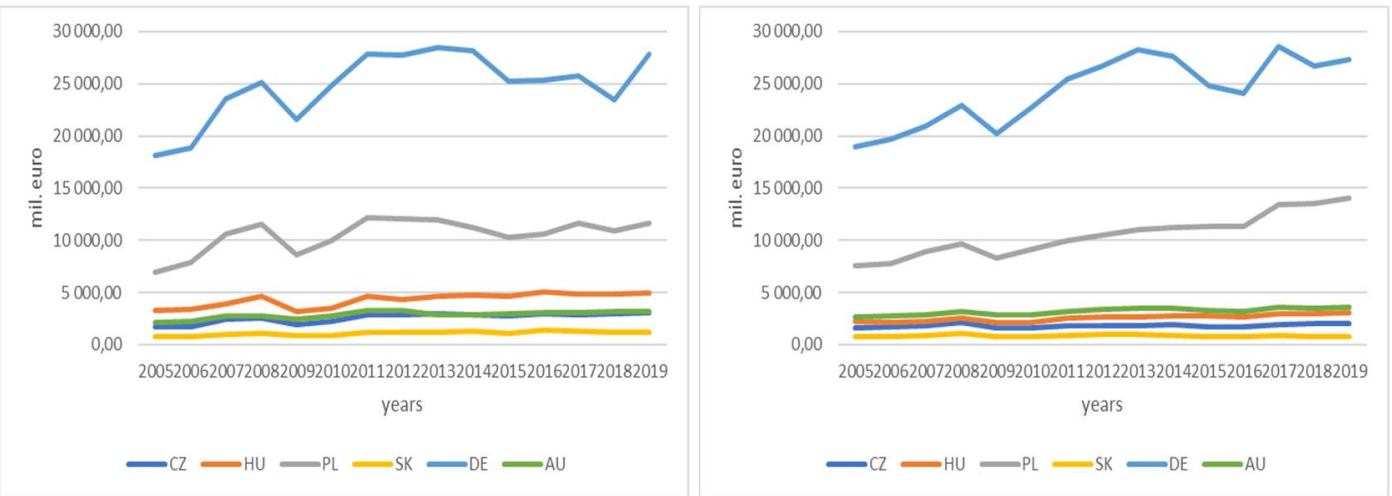

Source: EUROSTAT, own processing

It is evident that there is a significant oscillation of values for the indicators together with a significant growth difference. All indicators decline in 2009, when the financial crisis broke out. The fact is that livestock production has suffered significantly less in terms of production than crop production. 
The most significant increase between the years 2005-2019 is recorded in Poland for the indicators of total agricultural production $(+76 \%)$ and total livestock production $(+85 \%)$. The highest increase of total crop production for the given period is achieved in Czech $(+86 \%)$.

By the implementation of the index of total agricultural production, crop and animal production, it is possible to characterize the development of the agricultural production and its basic sectoral structures of the given years in comparison with the basic year 2005 (Fig. 3, 4).

Figure 3 Total agricultural production index $(2005=100)$

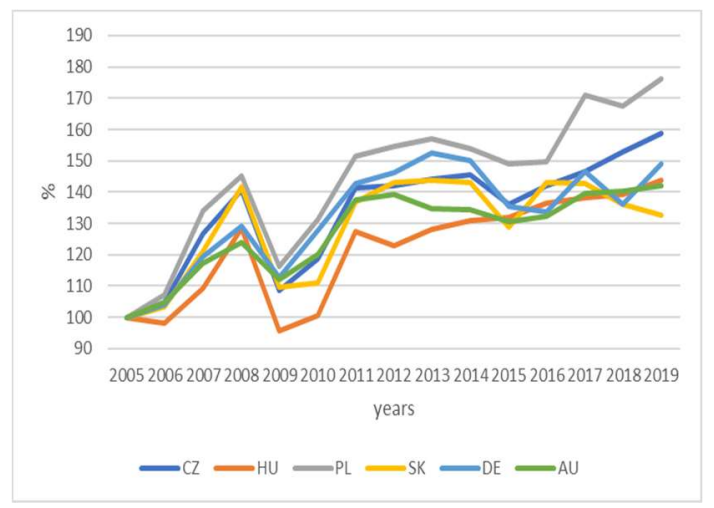

Source: Eurostat, own processing

Figure 4 Crop and livestock production index $(2005=100)$
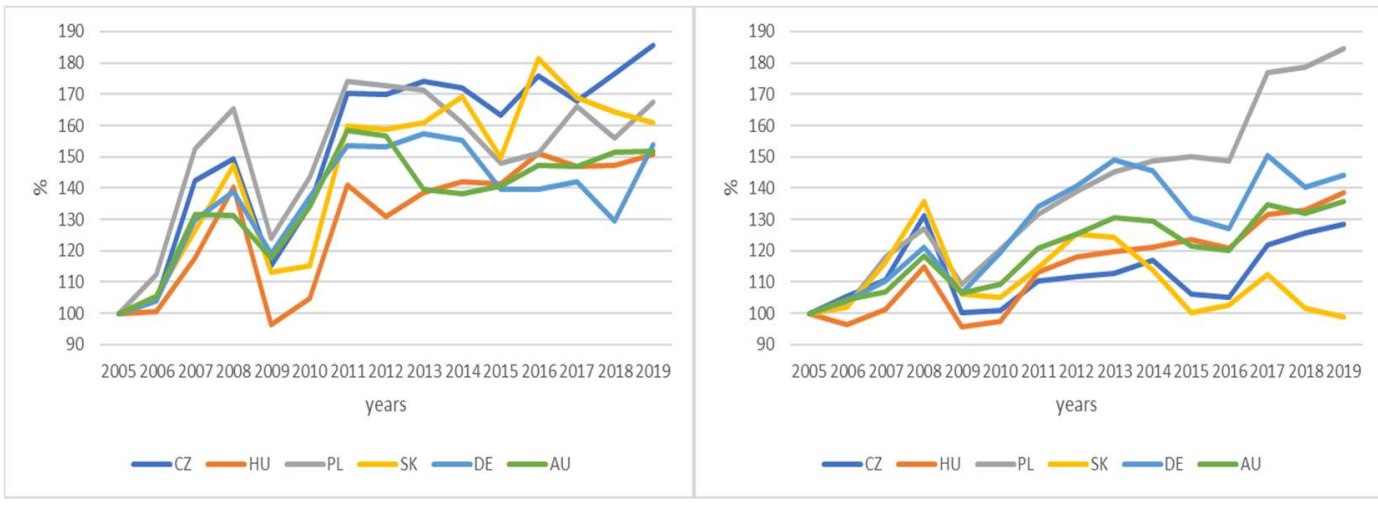

Source: Eurostat, own processing

The share of crop and animal production in total agricultural production in the case of Slovakia and the Czech Republic changed significantly between 2005 and 2019. In the case of Slovakia, the share of livestock production decreased by approximately $20 \%$ in favour of crop production. The Czech Republic is experiencing the same change, but the decline was "only" $10 \%$.

In 2005, the share of crop and animal production was as follows: the Czech Republic (51:49), Hungary (60:40), Poland (48:52) and Slovakia (50:50). 
In 2019, the share of crop and livestock production in total agricultural production in individual V4 countries in 2019 was as follows: Czech Republic (60:40), Hungary (62:38), Poland (45:55) and Slovakia (62:38).

In Germany and Austria, the representation of crop and livestock production was as follows in 2005: Germany: 49:51, Austria 44:56.

In last year 2019: Germany 50:50, Austria 47:53.

The data show that in all countries except Poland, Germany and Austria, the balance of the share of the two basic agricultural sectors in favour of crop production has been upset.

According to the Svatoš and Smutka (2013), the situation in the V4 countries in this area has been unchanged for a long time since the 1990s. The same is true for the fact that crop production faces much higher fluctuations compared to livestock production.

However, even in the given conditions, it is necessary to agree with Bańský's statement from 2008, that the main source of income in developed countries is animal husbandry.

This is the effect of a simple economic number - products of animal origin, as subject to a more advanced "processing" order for relatively higher prices than products of plant origin. In the monitored period, however, a decisive role in the agriculture of Central European countries plays primarily crop production. The importance of crop production was confirmed by a relatively high proportion arable land in the structure of agricultural land.

Tab 2 shows the development of the utilised agricultural area (UAA), the growing trend of this indicator between 2005 and 2018 is recorded in Hungary and Slovakia.

The share of agriculture area on total area of the countries is in the 2018 following: $\mathrm{CZ}$ $56,8 \%$, HU 64,7\%, PL 58,7\%, SK 47,1\%, DE 46,6\% and AU 31,6\%.

Table 2 Changes in the area of UAA

\begin{tabular}{|c|c|c|c|c|c|c|}
\hline \multicolumn{7}{|c|}{ UAA (1000 ha) } \\
\hline & 2005 & 2008 & 2010 & 2013 & 2016 & 2018 \\
\hline CZ & 3558 & 3518 & 3484 & 3941 & 3455 & 3523 \\
\hline HU & 4267 & 4229 & 4686 & 4657 & 4671 & 5344 \\
\hline PL & 14755 & 15477 & 14447 & 14410 & 14406 & 14540 \\
\hline SK & 1879 & 1937 & 1896 & 1902 & 1890 & 1920 \\
\hline DE & 17035 & 16932 & 16704 & 16700 & 16659 & 16645 \\
\hline AU & 3266 & 3189 & 2878 & 2727 & 2689 & 2654 \\
\hline
\end{tabular}

Source: EUROSTAT, own processing

In terms of agricultural land use, the ratio between UAA and arable land in the observed period is the highest in Hungary, where the degree of plowing after 2010 exceeds $80 \%$ of 
UAA. The second highest share is recorded in Poland 75\% (2016), but we can observe a slight decline in this indicator. In the Czech Republic, a decrease is also observed, which is more pronounced, there was a decrease of $2 \%$ and the resulting value is $72 \%$ of the UAA. The lowest share of arable land in the UAA is in Austria (50\% in 2016).

Specific data are given in Table 3.

Table 3 Changes in share of arable land and grassland on UAA (\%)

\begin{tabular}{|c|c|c|c|c|c|c|c|c|c|c|c|}
\hline \multicolumn{4}{|c|}{ Share of arable land on UAA (\%) } & \multicolumn{4}{c|}{ Share of grassland on UAA (\%) } \\
\hline & 2005 & 2008 & 2010 & 2013 & 2016 & & 2005 & 2008 & 2010 & 2013 & 2016 \\
\hline CZ & 74 & 74 & 73 & 72 & 72 & CZ & 25 & 26 & 27 & 28 & 27 \\
\hline HU & 78 & 78 & 81 & 81 & 81 & HU & 17 & 17 & 14 & 14 & 15 \\
\hline PL & 77 & 77 & 75 & 75 & 75 & PL & 21 & 21 & 22 & 22 & 22 \\
\hline SK & 70 & 69 & 71 & 72 & 71 & SK & 28 & 29 & 28 & 27 & 28 \\
\hline DE & 70 & 70 & 71 & 71 & 71 & DE & 29 & 29 & 28 & 28 & 28 \\
\hline AU & 43 & 44 & 48 & 50 & 50 & AU & 55 & 54 & 50 & 48 & 47 \\
\hline
\end{tabular}

Source: EUROSTAT, own processing

Typical for the Czech agriculture is the increase in the area of permanent grassland at the expense of arable land after accession to the EU (Krejčí et al., 2019). On the contrary, the share of permanent grassland in other countries does not change significantly. By far the highest share of grasslands is in Austria. This is due to the significantly low share of arable land in agricultural land, which is due to the soil conditions of the local area. However, we have seen a declining trend in this indicator in the last decade.

The overall and structural development of agriculture and its effectiveness, including the specific application of CAP instruments, were logically reflected in the development of individual regions of V4 countries. Focus on in more detail.

\section{Development of agricultural sector in Cohesion Regions of the V4 countries during decade of association to EU}

The input data for the statistical analyses of beta and sigma convergence are the values of indicators at the level of NUTS 2 regions (Cohesion Regions) of the V4 countries: total value of agricultural production, value of total crop production and value of total livestock production in millions of euro.

The level of NUTS 2 regions has been deliberately chosen in order to assess the agricultural situation in the V4 countries as precisely as possible, which is facilitated by the lower nomenclature of statistical territorial units. 
The Czech region NUTS 2 - Prague was not included in the analyses. This region has a different characteristic from the other regions and showed zero for all indicators throughout the observation period.

The marking of V4 Cohesion Regions in the paper is as follows:

- C1-C8 Czech Republic: C1 Praha, C2 Střední Čechy, C3 Jihozápad, C4 Severozápad, C5 Severovýchod, C6 Jihovýchod, C7 Střední Morava, C8 Moravskoslezko,

- H1-H7 Hungary: H1 Közép-Magyarország, H2 Közép-Dunántúl, H3 Nyugat-Dunántúl, H4 Dél-Dunántúl, H5 Észak-Magyarország, H6 Észak-Alföld, H7 Dél-Alföld,

- P1-P16 Poland: P1 Lódzkie, P2 Mazowieckie, P3 Malopolskie, P4 Slaskie, P5 Lubelskie, P6 Podkarpackie, P7 Swietokrzyskie, P8 Podlaskie, P9 Wielkopolskie, P10 Zachodniopomorskie, P11 Lubuskie, P12 Dolnoslaskie, P13 Opolskie, P14 KujawskoPomorskie, P15 Warminsko-Mazurskie, P16 Pomorskie,

- S1-S4 Slovakia: S1 Bratislavský kraj, S2 Západné Slovensko, S3 Stredné Slovensko, S4 Východné Slovensko.

The input data of analyzes are slightly asymmetric on the left. The median values of the indicators increase over time, indicating that the initial significant gap between regions is widening. However, the data do not show extremes or outliers, so it was not necessary to logarithmize them.

For the overall assessment it should be taken into account, that the soil and climatic conditions are different in the mentioned regions.

From the point of view of Less Favored Areas (LFA), Slovakia has the least favorable conditions from selected countries, where only $25 \%$ of UAA is outside of the LFA and $35 \%$ of arable land.

The remaining V4 countries move similarly in both indicators, with about $50 \%$ of the area being outside of the LFA.

Specifically, when applying the statistical method of beta convergence, in the case of the total value of agricultural production indicator (Fig. 3.), the regression line takes the form: $y=$ $6 \mathrm{E}-06 \mathrm{x}+1,0336$, which implies that $\beta>0$. However, the trend is not significant since the coefficient of determination reaches $100 \mathrm{r}^{2}=3,6 \%$. 
Figure 5 Beta convergence of the values of total agricultural production (in the years 20052015)

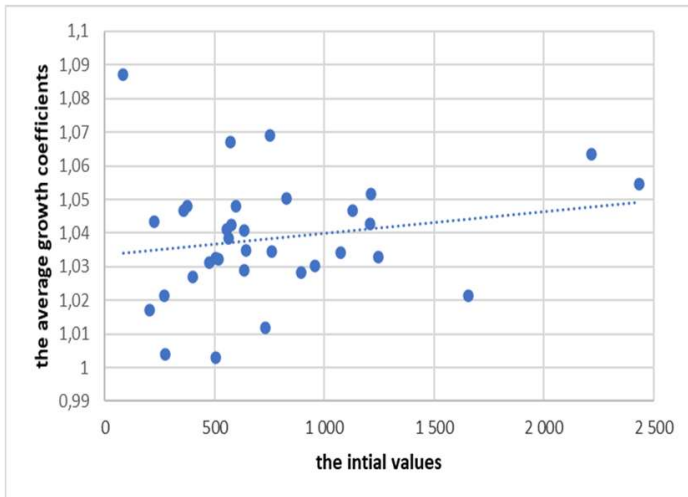

Source: EUROSTAT, own processing

For the total value of plant production, beta convergence has the form of a regression line: $y=1 \mathrm{E}-05 \mathrm{x}+1.0401, \beta>0$, the coefficient of determination is $100 \mathrm{r}^{2}=3,5 \%$. The indicator of the total value of livestock production is described by a regression line in the form $y=2 \mathrm{E}-05 \mathrm{x}$ $+1.0165, \beta>0$, the coefficient of determination is $100 \mathrm{r}^{2}=6,9 \%$.

Figure 6 Beta convergence of the values of total crop production and beta convergence of the values of total livestock production (in the years 2005-2015)
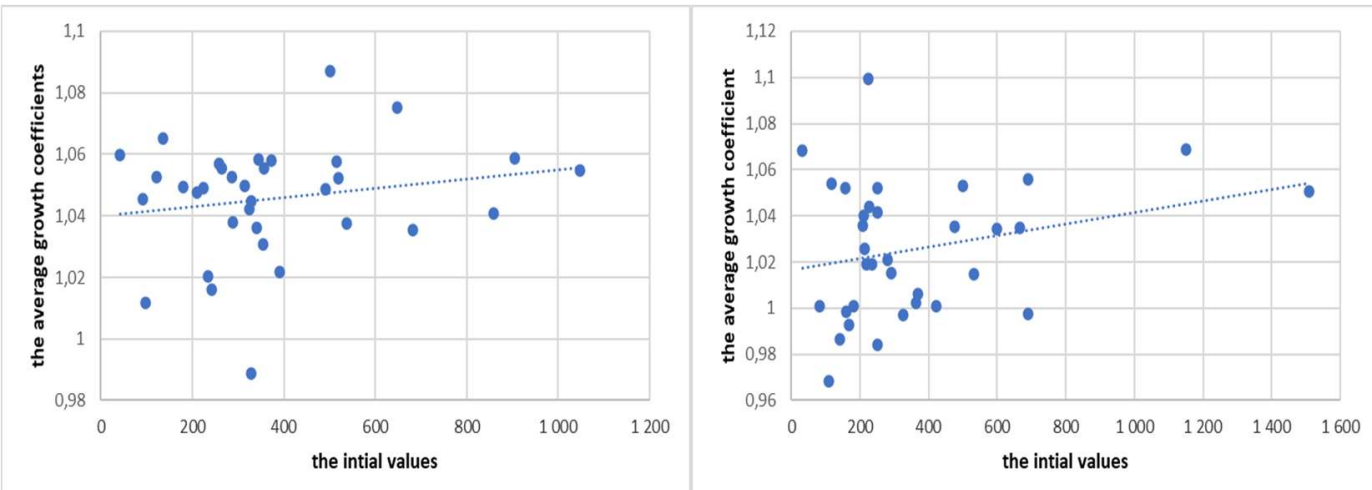

Source: EUROSTAT, own processing

In all cases, $\beta>0$, which implies, that the lines are only increasing in shape. There is a tendency for divergence between the regions for all the examined indicators. Regions are moving away from each other.

By means of the sigma convergence analysis, presented in the Fig. 10, it is evident that the course in the monitored period 2005-2015 is accompanied by a significant oscillation of values. Again, there is a significant decrease in the standard deviation in 2009, when the variability of values of all indicators decreased. 
Figure 7 Sigma convergence: total agricultural production values, total crop production values and total livestock production values (2005-2015)

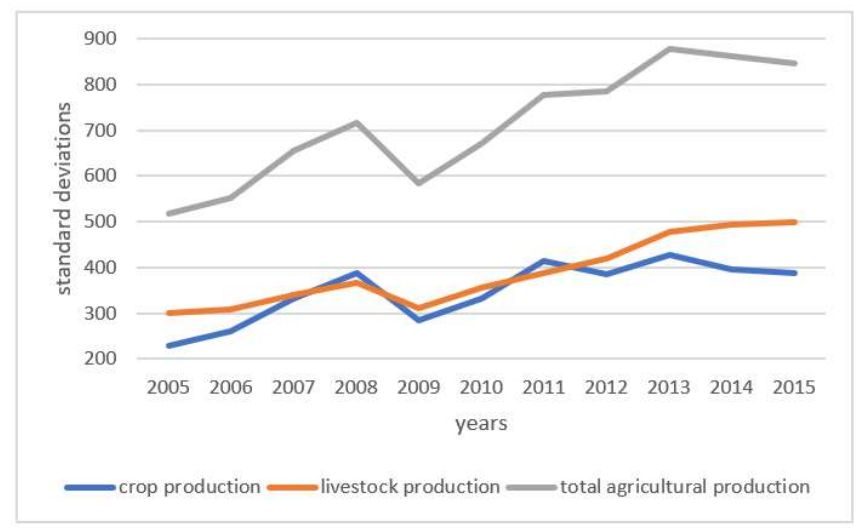

Source: EUROSTAT, own processing

In the case of indicators of total value of agricultural production and total value of crop production, a similar course is observed.

Between the years 2005 and 2008 there is a divergence tendency between NUTS 2 regions, then there is a significant decline between 2008 and 2009. In this period, the regions converge.

From 2009 to 2013, we again observe the tendency to diverge. Convergence tendencies then appear at the end of the examined period (2013-2015).

The total livestock production indicator over the entire observation period (2005-2015) shows only a divergence tendency, except for a decline (convergence tendency) between 2008 -2009. This is because the standard deviation of values is increasing, and so is the variability between regions that are moving away from each other.

In the case of beta convergence, only low coefficients of determination were achieved in the above-mentioned indicator analyses. Thus a correlation diagram was created and evaluated according to Minaŕík (2014), Management association (2017). It shows that no significant evidence of divergence in any of the monitored indicators was confirmed.

Figure 8 Correlation diagram of total value of agricultural production (2005-2015)

Source: EUROSTAT, own processing

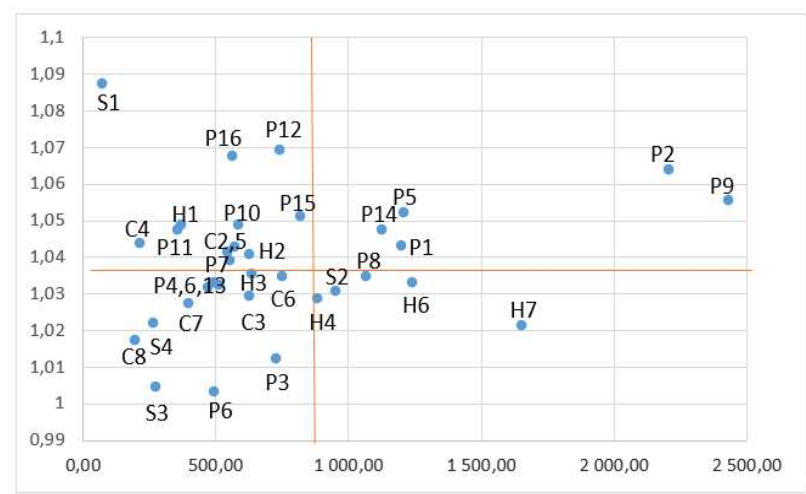


Figure 9 Correlation diagram of value of total crop production and correlation diagram of total value of total livestock production (2005-2015)
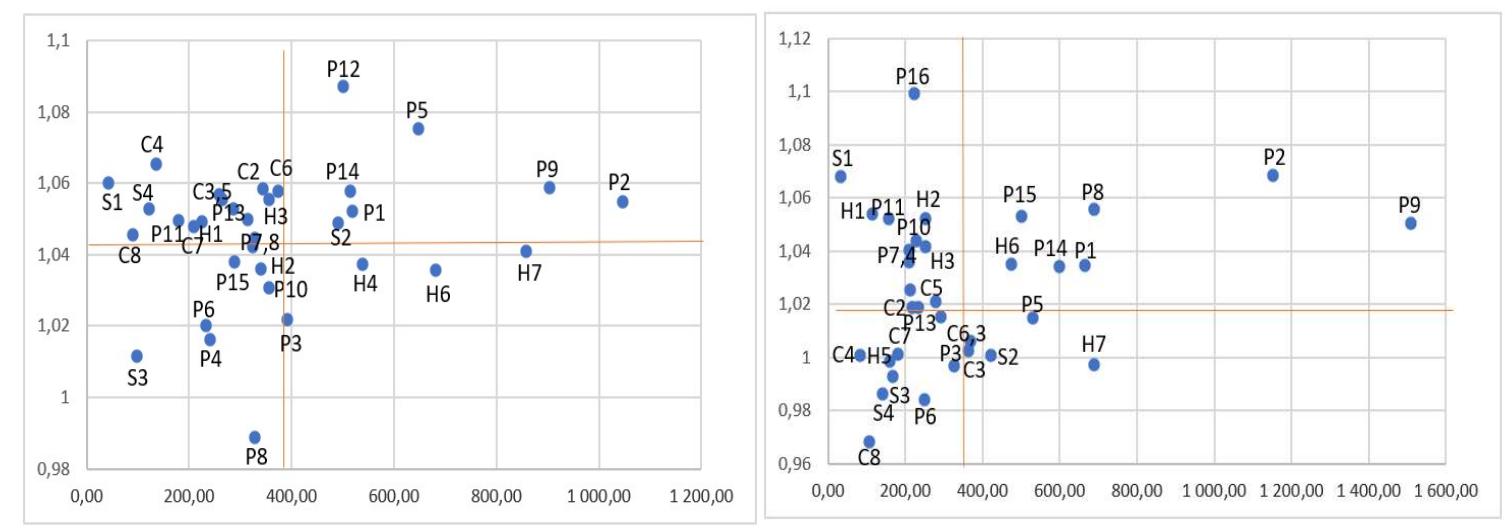

Source: EUROSTAT, own processing

As can be seen from Fig. 8, and 9, it is clear that with some exceptions, the regions of Poland reach the first quadrant for all indicators. These regions initially showed higher values of the monitored indicators and showed high growth rate in the observation period. In the future, we can assume that these regions will move away from other regions in given indicators.

The Polish regions were also located in the second quadrant with a high frequency, confirming their above-average growth rate in selected indicators, which shows the realization of growth potential in the Polish regions.

In the case of all regions of the Czech Republic there was an above-average growth rate in the indicator of the value of total crop production, as for the livestock production the results are disturbing due to the localization of three regions in the III. quadrant and two regions in the IV. quadrant for the indicator of total livestock production value.

A similar situation in Slovakia is observed, there is also an apparent trend of decreasing livestock production, which is compensated by plant production. In the case of the Cohesion Regions of Hungary, we observe a significant deterioration of the situation, especially in the indicator of the crop production value.

A general overview of the development and structure of agriculture in the Cohesion Regions in the V4 countries follows from the Fig. 10. 
Figure 10 Classification of NUTS 2 regions of V4 countries into quadrants by total agricultural production value, total crop production value and total livestock production value

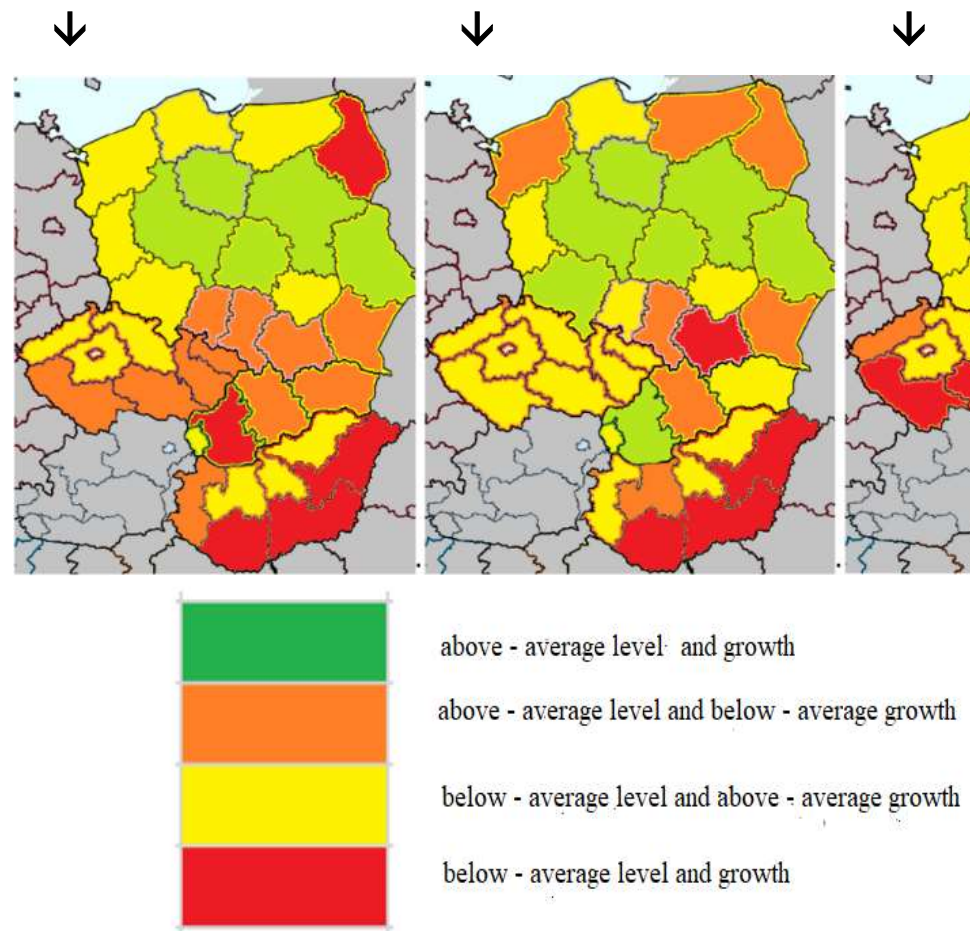

Source: EUROSTAT, own processing

Based on the evaluation of beta convergence indicators between NUTS 2 regions of the V4 countries between 2005-2015 the trend of divergence can be observed for the examined indicators, but only a low value of the coefficient of determination is achieved.

Subsequent analyses using correlation diagrams did not confirm significant divergence tendencies. In the case of the indicators of total value of agricultural production, indicators of total value of crop and livestock production, they grew in all V4 countries, with the most significant increases in the value of total agricultural production and value of total livestock production in Poland and in value of total crop production in the Czech Republic. It is also necessary to mention the different agro-ecological conditions, which together with the influence of weather play a greater role in the agrarian sector at the regional level.

Overall, all indicators showed a good position of Polish regions, which with some exceptions were located in the first quadrant of correlation diagrams, which is related to realization of the economic potential of this country and its regions. The research also shows a significant increase in the efficiency of Polish agricultural production. It can be assumed that the development of these regions is also positively affected by the use of higher forms of processing of domestic as well as imported raw materials and the possibility of their finalization. 
In this context, Komarowska (2014) states that Poland's accession to the EU has led to relatively large changes in agriculture compared to other economic sectors, which have been accompanied by an addictive transformation of the functioning of Polish agricultural and rural areas. Votava and Bačina (2009) see the preference of Polish agriculture in the interconnection of production, post-harvest treatment, storage and distribution ,under one roof". This is the strong competition of Polish agriculture and, on the contrary, the threat to primary agricultural producers in other V4 countries.

It is indisputable that a number of factors, including the previous systems operating in these countries, as well as conditions and the timing of their implementation after the Eastern Enlargement in 2004 influenced the overall development. At the same time, the EU CAP itself underwent a change in the conditions attached to the application of the Fischler's reform, which to some extent further partially complicated the situation, for example, in the possibility of the new Member States entering the common market.

In addition, the influence of the WTO that led the EU to greater market liberalization towards the third countries was not negligible at that time as well, which was reflected in the CAP in particular by the commodity price support reduction and by choice of other forms of interventions.

Based on the Mid Term Review of the CAP, the stabilization of the agricultural budget for the period 2006 to 2012 and subsequently the Health Check in 2008 and other measures after 2013, relatively fundamental reform steps were implemented. In particular, major measures in the area of market organization aimed at reducing the impact of instruments that directly interfered with the agricultural market and hindered its liberalization.

\section{CONCLUSION}

It is indisputable that the accession of the Visegrad countries to the European Union, the application of the Common Agricultural Policy and the expansion of the agricultural market have had a positive effect on the overall growth of agricultural production. Based on the results of the overall analyses the development of the size and structure of agricultural production in the 35 Cohesion Regions of the Visegrad Group countries (in the Czech Republic, Poland, Hungary and Slovakia) in the decade period 2005-2015 it can be stated that is has not been confirmed proclaimed effort to bring these regions closer together.

The development of the agricultural sector of the V4 countries was largely influenced by changes in the CAP, which were applied in the given period, and rural development was based on activities that result in sustainable economic profit, stabilization of local population 
in rural regions, and improving the quality of life there (Škodová Parmová, 2011). The integration and competitiveness of individual agricultural holdings in the common European market have also proved largely.

These approaches were subsequently in the development of the agricultural sector in the monitored Member States reflected. By Madra-Sawicka, et al. (2019), countries have a different position in relation to the specificities of the agricultural sector. Based on the evaluation of its development and characteristics of development trends in the regions, it is possible to specify the impact on differences in national strategies within the CAP application.

It is already clear that the success or failure of Member States' individual approach to the CAP will have a decisive impact on the very development of individual countries and their regions (Loriz-Hoffmann, 2020).

The new programming period, 2021-2027, will bring many changes. Member States will gain more flexibility and responsibility in the new programming period. Their task is to create a Strategic Plan of the country and its submission to the EC, which will be evaluated on basis of factsheet the determination and level of specific indicators related to the fulfillment of the nine objectives of the future CAP. As the preparation of the information sheet requires an overview of the development of the agriculture and rural development, including data to justify the specific objectives of the implementation, the theoretical approach, implication methods and results of the presented research for argumentation in terms of solving a specific goal and mutual interactions with other goals can be used.

Whereas the total amount of support provided, as well as sectoral support allocation, play an important role in agricultural sector development, knowledge gained from a proven comparison also leads the focus and deepening of further research related to the focus and effectiveness of state intervention, conditions of the development and co-financing of the proposed measures. In this context, too, it is necessary to assess the extent to which the development of internal and external conditions of the business environment in the agricultural market is motivating for agricultural producers, processors and consumers.

The strategy for the development of a modern European model of multifunctional agriculture, which is discussed in the concept for the future CAP, is immediately confronted with new challenges arising not only from accelerating globalization processes but also from knowing the conditions of a particular business environment and the ability to use them. The success of a solution in the production area is reflected increasingly in all dimensions (economic, ecological, technological, as well as human and social) of the development of regions and society as a whole. 


\section{REFERENCES}

Alexiadis, S. (2010). Convergence in Agriculture: Evidence from the European Regions. Greek Association of Agricultural Economists 11(2), 84-96. DOI: 10.22004/ag.econ.118866.

Bacsi, Z., \& Kovács, E. (2007). Development Features of Cross-Border Regions. KeszthelyHéviz Kistérségi Többcélú Társulás Retrieved from: https://www.researchgate.net/publication/303309767_Development_Features_of_CrossBorder_Regions.

Banister, D., \& Berechman, J. (2000). Transport investment and economic development. London: UCL Press. DOI: 10.4324/9780203220870.

Bański, J. (2008). Contemporary Changes of Agriculture in East-Central Europe. PAN IG $i$ $P Z, 7-20$.

Baráth, L., Nagy, S., \& Szabó, G. (2010). The correlation between the agricultural productivity and the export performance of the agro-food foreign trade in the Visegrád Group countries following accession to the European Union. Studies in Agricultural Economics, 55-68. DOI: 10.22004/ag.econ.93122.

Barro, R., \& Sala Martin, X. (1995): Economic Growth, McGraw Hill, New York.

Baumol, W. (1986). Productivity Growth Convergence and Welfare. American Economic Review, vol. 76, 1072-108.

Bečvářová, V., \& Zdráhal, I. (2013). Agriculture and Rural Development in the European Model of Agricultural Policy - Shaping Strategy in the Context of Environmental Changes. Mendel University in Brno, 144.

Bečvářová, V. (2005). The Scope as well as the Opportunity for Contemporary Agriculture. Agricultural Economics. 51: 285-292. DOI: 10.17221/5109-AGRICECON.

Bečvářová, V. (2008). Vývoj českého zemědělství v evropském kontextu. Mendel University in Brno. 62.

Blažek, J., \& Uhlír, D. (2002). Teorie regionálního rozvoje: nástin, kritika, implikace. Karolinum. 211.

Csaki, C., \& Jambor, A. (2019). Convergence or divergence - Transition in agriculture of Central and Eastern Europe and Commonwealth of Independet States revisited. Agricultural Economics - Czech. DOI: 10172211952018.

Edward, M., \& Clifford, S. (2005). Reframing Agribusiness: Moving from Farm to Market Centric. Journal of Agribusiness, 23(1). 1-17. DOI: 10.22004/ag.econ.59611.

EU Commission (2009). European Competitiveness Report 2008. Brussels.

Gaspár, A. (2012). Convergence analysis: a new approach. MPRA Paper 40363.382-390 Retrieved from: https://mpra.ub.uni-muenchen.de/40363/.

Hansen, H., \& Herrmann, R. (2012). The two dimensions of policy impacts on economic cohesion. Elsevier. 37 (4), 483-491. DOI: 10.1016/j.foodpol.2012.02.008.

Islam, N. (2003). What have we learnt from the convergence debate? Journal of Economic Surveys, 17: 309-362. DOI:10.1111/1467-6419.00197.

Jambor, A. (2013). Comparative Advantages and Specialisation of the Visegrad Countries Agri-Food. Acta Oeconomica et Informatica, 16 (1), 22-34. DOI: 10.22004/ag.econ.144684.

Jong, W. (2018). Structural convergence between the dairy sectors of the EU-27 Member States. European Association of Agricultural Economists, 25. DOI: 10.22004/ag.econ.271959.

Komorowska, D. (2014). Prawidłowości rozwoju rolnictwa a rozwój współczesnego rolnictwa, Wieśs and Agriculture, 71-84. Retrieved from 
http://agro.icm.edu.pl/agro/element/bwmeta1 .element.agro-948736d4-788a-4b2b-a83b$39 \mathrm{aa} 20 \mathrm{~d} 1 \mathrm{c} 7 \mathrm{c} 0$.

Krejčí, T., Navrátil, J., Martinát, S., Pícha, K., \& Klusáček, P., Osman, R., Škrabal, J. (2019). Current use of former communist agricultural properties in South Bohemia. 22nd International Colloquium on Regional Sciences. Conference Proceedings, 665-671.

Loriz-Hoffmann, J. (2020). The new CAP post-2020: general architecture and focus on EAFRD \& financial instruments. EC. Retrieved from: https://www.ficompass.eu/sites/default/files/publications/EAFRD_Sofia_JosefineLorizHoffmann_0.pd $\mathrm{f}$

Madra-Sawicka, M., Franc-Dabrowska, J., Kotyza, P., Slaboch, J., Hornowski, A,. \& Smutka, L. (2019). The Development, Structure and Changes in Direct Support after EU Accession in the Czech Republic and Poland. Agrarian perspectives XXVIII. business scale in relation to economics, 98-106. Retrieved from: https://www.researchgate.net/profile/Pavel_Kotyza/publication/336530024.

Management association (2017). Natural resources management: concepts, methodologies, tools and applications. USA: IGI Global, 1647. Retrieved from: https://books.google.cz/books?id=PRwRDQAAQBAJ\&amp;pg=PA787\&amp;dq=beta+ and + sigma + convergence\&amp;hl=cs\&amp;sa=X\&amp;ved=2ahUKEwjusunN-.

Massot, A. (2018). Společná zemědělská politika po roce 2020. Europarl.europa.eu. Retrieved from: http://www.europarl.europa.eu/factsheets/cs/sheet/113/spolecnazemedelska-politika-po-roce-2020.

Minařík, B., Borůvková, J., \& Vystrčil, M. (2013). Analýzy v regionálním rozvoji. Praha: Professional Publishing, 244.

Minařík, B. (2014). Statistické minimum pro studenty bakalářského studia na technických oborech. Jihlava: Vysoká škola polytechnická Jihlava, 96.

Monfort, P. (2008). Convergence of EU regions Measures and evolution. EU Regional Policy, 20.

Retrieved

from:

https://ec.europa.eu/regional_policy/sources/docgener/work/200801_convergence.pdf.

Nevima, J., \& Melecký, L. (2008). Analýza beta-konvergence regionū zemí Visegrádské čtyřky prostřednictvím nelineárního regresního modelu. Acta Academica karviniensia, 11(3), 43-57. DOI: 10.25142/aak.2011.045.

Obstfeld, M., \& Rogoff, K. (1996). Foundations of international macroeconomics. Cambridge, MASS: MIT Press.

Scown, M., Brady, M., \& Nicholas, K. (2020). Billions in Misspent EU Agricultural Subsidies Could Support the Sustainable Development Goals. Science Direct, One Earth 3(2), 237-250. DOI: https://doi.org/10.1016/j.oneear.2020.07.011.

Škodová Parmová, D. (2011). Diversification as a factor for sustainable rural development. Jahrbuch der Österreichischen Aesellschaft für Agrarökonomie, 43-52. Retrieved from: $\mathrm{http}: / /$ citeseerx.ist.psu.edu/viewdoc/download?doi=10.1.1.477.3083\&rep=rep1\&type $=\mathrm{p}$ df\#page $=57$.

Solow, R. (1956). A Contribution to the Theory of Economic Growth. The Quarterly Journal of Economics. DOI: 10.2307/1884513.

Spišiak, P., Ferenc, J., Ot’ahal, J., \& Nováček, J. (2008). Transition in the agricultural and rural system in Slovakia after 1989. PAN IG i PZ, 121 - 146, 227

Svatoš, M., \& Smutka, L. (2011). The analysis of individual Visegrad Group Members', Agrarian Export Sensitivity in Relation to Selected Macroeconomic Aggregations. Acta, Universitatis Agriculturae and Silviculturae Mendelianae Brunensis, 59(4). DOI: 10.11118/actaun201159040327. 
Svatoš, M., \& Smutka, L. (2013). Development of Visegrad Countries’ Agricultural Trade in Relation to Agricultural Production Development. AGRIS on-line Papers in Economics and Informatics. DOI: 10.22004/ag.econ.148104.

Svatoš, M. (2009). Multifunkční zemědělství v rámci národní strategie udržitelného rozvoje. AGRIS on-line Papers in Economics and Informatics. Retrieved from: http://www.agris.cz/Content/files/main_files/59/136901/svatos.pdf [cit. 2020-05-26].

Swinnen, J. \& Vandeplas, A. (2015). Price Transmission in Modern Agricultural Value Chains: Some Conceptual Issues. In Food Proce Dynamics and Price Adjustment in the EU. Oxford Scholarship. DOI:10.1093/acprof:oso/9780198732396.003.0007.

Votava, J., \& Bačina J. (2009). Polish agriculture. Asociace soukromého zemédělství ČR. Retrieved from: 1url.cz/wKiU4..

Wittmer, H., \& Gundimeda, H. (2012). The Economics of Ecosystems and Biodiversity in Local and Regional Policy and Management. London: EARTHSCAN, 351.

Zgliński, W. (2008). The Essential Problems and the Structure of Polish Agriculture in Period of Transformation. PAN IG i PZ, 45-72, 227.

Zylbersztajn, D. (2017). Agribusiness systems analysis: origin, evolution and research $\begin{array}{llll}\text { perspectives. } & \text { Science } & \text { Direct, }\end{array}$ https://doi.org/10.1016/j.rausp.2016.10.004. 